\title{
Major Determinant of Physical Development on Urban Residential Land: The Case of Kalulushi Municipality in Zambia
}

\author{
Ephraim Kabunda Munshifwa ${ }^{1}$, Wilson Ngoma $^{2}$, Ikugile Makenja ${ }^{2}$ \\ ${ }^{1}$ School of the Built Environment, Copperbelt University, P.O Box 21692, Kitwe, Zambia \\ ${ }^{2}$ Department of Real Estate Studies, School of the Built Environment, Copperbelt University, P.O Box 21692, Kitwe, \\ Zambia
}

Correspondence: Ephraim KabundaMunshifwa, School of the Built Environment, Copperbelt University, P.O Box 21692, Kitwe, Zambia.

Received: April 25, 2017

Accepted: May 16, $2017 \quad$ Available online: May 22, 2017

doi:10.11114/ijsss.v5i6.2434

URL: https://doi.org/10.11114/ijsss.v5i6.2434

\begin{abstract}
The debate on "property" as opposed to "possession" has grown in institutional economics literature. In the real estate development context this can be extended to examining the question on what the major determinant of commencement of physical development (or 'house starts') is between 'property' and 'possession' in the minds of residential allotees on urban land. For land acquired through extra-legal mechanisms, economists, such as Hermandode Soto, have argued that lack of title impedes physical development in urban areas. What about on land acquired through legal means? This study examined this question by conceptualising land grants through the public land allocation system as having two distinct parts, possession, that is grants still at offer letter stage and property, constituting grants where legal title in the form of certificates of title have been registered. The observation in Zambia is that physical development commences with or without certificates of title, that is, mostly at possession stage. This study finds that contrary to conventional literature, titling is not the immediate concern for most allotees on public land. The first concern is development of the plot then followed by title. Anumber of reasons account for this and are explained in this paper. Thus the study hypothesised that although in the long run legal title is essential, possession is more important for the commencement of physical development in most developing countries such as Zambia.
\end{abstract}

Keywords: housing development, possession, property, public land, titling, Zambia

\section{Introduction}

\subsection{Defining the Problem}

Zambia, like a number of countries in Sub Saharan Africa (SSA), has a peculiar system of granting land rights through a public administrative land allocation system. Unlike in Western countries where the market is more dominant in allocating rights to resources, the Zambian system depends on detailed state rules and regulations administered through state and local authority organizations and agents. This allocation comes with a condition derived from the Lands Act of 1996, which stipulates that development should be completed within 18 months but should not commence on offer letters (GRZ, 1996). The Lands and Deeds Registry Act of 1914 (amended over time) further stipulates that land acquired through this system should also be titled for it to convey legal ownership (GRZ, 1914). Thus a scenario emerges where terms and conditions on the allocation stage requires that the plot be fully developed within 18 months from physical allocation while the process on titling, which in many cases takes more than 18 months, warns that only title is legally recognised as sufficient evidence of ownership. The key question then is what option do developers choose and why?

Literature has extensively argued that lack of title impedes physical development in urban areas, especially on land acquired through extra-legal arrangements (see de Soto, 2000; Navarro \& Turnbull, 2013). The understanding is that the security of formal title and property rights creates an incentive for owners to invest in improvements (Besley, 1995; Besley and Ghatak, 2009). Alternatively once title is given to residents of these extra-legal settlements, physical development would then proceed apace. Alternatively, this argument can be restated to imply that legal title is the major determinant of physical development on urban land.

Perceived within institutional economics literature debate, grants still at offer letter stage in the legally allocated parts of 
the urban areas are conceived as possession while those processed to title stage through the Lands and Deeds Registry Act as property. Conceptualized as such, this study then investigated the major determinant of commencement of physical development ${ }^{1}$ on urban residential land between possession and property. This study uses data from Kalulushi Municipality, one of the local authorities on the Copperbelt Province of Zambia, where over 1600 plots have been allocated in recent years and are at various stages of ownership and de velopment. It hypothesise $d$ that although in the long run legal title is important, possession is more important for the commencement of physical development in most developing countries such as Zambia.

Following this background, the rest of the paper discussed empirical literature on major determinants of physical development urban areas, the theoretical viewpoint, outlined the research methodology and highlighted the areas for policy consideration.

\subsection{Background to the Study}

As stated earlier, Zambia's land administration system has an elaborate structure of an organizational framework of state and local authority agencies supported by an institutional structure of laws, rules, processes and procedures. Thus a brief description of the essential parts of this system at this stage will provide an insight on the discussion in later parts. In this system the process of acquiring land often starts with the local authority in whose jurisdiction the land is situated. With delegated powers from the Commissioner of Lands, local authorities are empowered to advertise plots available for allocation in their areas and process applications to the stage of issuing recommendation letters ${ }^{2}$. These letters essentially provide details, should the Commissioner of Lands opt to allocate. These details include applicant's name, stand number (land description), location (low/middle/high cost areas) and council minutes (proof of allocation by full council meeting). On the basis of these recommendations, applications are then forwarded to the Ministry of Lands, Natural Resources and Environmental Protection for further processing.

The starting point at the Ministry is the Commissioner of Lands department where final offer letters are issued. At this point the local authority then proceeds to physically show the plot to the allotee. Since most land is allocated un-surveyed and un-serviced, it then becomes the responsibility of the allotee to cadastrally survey the plot, often through hired private land surveyors. The survey diagrams are inspected and approved by the Surveyor General's office whereupon these become legal documents. On submission of this survey diagram to the Lands and Deed's Registry office, together with standard terms and conditions, a certificate of title is then produced, conceptualized in this study as legal title (property). This system is mostly a remnant of the British colonial government with the first Act having been passed as the Lands and Deeds Registry Act No. 15 of 1914; way before Zambia's independence in 1964. Kalengwa in Kalulushi Town on the Copperbelt Province is one of the are as in Zambia where state land is allocated and registered through this system.

\subsection{Determinants of Physical Development in Urban Areas: A Literature Review}

An extensive review of literature revealed that while there was a lot of material available on related themes such as land administration, land governance, property rights and land titling, there were very little scholarly works that examined the behaviour of allotees in the context of public land allocated for individual private use through an administrative allocation system. For instance there was an abundance of literature on land administration in support of various facets of development such as economic, social, environmental, etc. (Dale and McLaughlin, 1988; Se vatdal, 2002; Enemark, 2003; Steudler, 2004; UNECE, 2005; Osterberg, 2006; Enemark and van der Molen, 2006; Williamson et al., 2006; Arko-Adjei, 2011). Literature on the related theme of land governance, defined as the manner in which power is exercised by government (Enemark, 2012), has recently become louder as an extension to the literature on land administration. Examples include Crabtree-Condor and Casey (2004), Enemarket al. (2010), Palmer et al. (2009), Amanor (2012) and Deiningeret al. (2012).

Another set of literature discusses land registration and its effect on land tenure security, facilitation of land market operations, improving of access to agricultural credit, generating of investments, raising of income levels and increasing of economic growth (Alhassan and Manuh, 2005). De Soto (2000) particularly regards it as the magic formula for poverty reduction and the solution to the development problems of developing economies. Kanji et al. (2005) see it as a means to livelihoods and promotion of sustainable development. Still others argue that lack of registration leads to land disputes (Domeher and Abdulai, 2012). However in a number of cases, land titling has not been a solution to the problems it is

\footnotetext{
${ }^{1}$ Similar to "house starts" in the UK (see for instance the "House Building: March Quarter 2016 England" booklet produced by the Department for Communities and Local Government in the UK). A difference is made between house building "starts" and "completion".

${ }^{2}$ Acouncil recommendation letter is simply an administrative document and thus offers no legal rights to the allotee, hence conceptualising it as 'possession' in this study.
} 
argued to solve. For example Alhassan and Manuh (2005) cited a number of problems in land registration including complex, slow and cumbersome procedures, and a weak institutional capacity of government agencies. This was argued to result in corruption, double registration and missing land records.

However the context of this study was to understand the choice making behaviour of allotees on public land given two conflicting policy positions; that iscommencing development on possession only and risking tenure insecurity or waiting for titling which may take longer than the stipulated period in the development code and still risk repossession of the plot. These allocations were similar in context to the allocation of public land in western countries. For instance Hickey and Sturtevant (2015) in their investigation of public land allocation for affordable housing in the Washington DC area found that such policies contribute to reducing development costs, increase development opportunities for affordable housing and help to meet the needs of lower income earners. While for America and most western countries allocation of public land is a very small component of urban development, in the majority of developing countries such as Zambia, the whole system of land de velopment is based on the primary and initial grant through this public system. In other words, all land is public land and granted for private use for limited periods under leasehold systems. Thus acquisition through the land market is a secondary activity.

These allocations were often premised on government policy of ensuring that vulnerable members of society can afford decent housing. Some scholars compared this form of residential urban de velopment to incremental housing - a process which begins with vacant plots (site and service) based on the principles of self help housing (Chavez, n.d; Tipple, 1991). This notion on protecting public land for the welfare of the vulnerable, development and infrastructure was also echoed by Haran (2013) in the case of the Government of Kerala in India. Zimmermann (2007) similarly argues for a public land governance system which contributes to a basic set of development principles such as poverty reduction. Thus this system is seen as the cheapest means of providing housing, especially in developing countries.

The development of unregistered land was not uncommon in most parts of Sub Saharan Africa (SSA), although in most studies the focus was on extra legal developments. For example, Maoulidi (2004) reported that in Tanzania most urban residents live in properties built on land without certificates or registered land rights. The study further reported that most residents believed their rights were secure, as evident by their investing in improvement of their plots and houses. The study was supported by findings by the Lands Commission which also found that a high percentage of Tanzanians were without titles, resulting in high incidences of double allocation and land disputes. Derby (2002) also observed the allocation of land to its most productive use, implementation of a sound land information management system, registration of all land rights and electronic storage of information as important steps to ensure rapid social and economic development.

While it is clear that there is an abundance of literature on property rights, land governance and administration, land registration and similar themes, this study found very little scholarly work which examined the behaviour of allotee on commencement of physical development in the context of public land allocated for individual private use in urban areas. For instance it is clear that most studies on land registration focus on the title deed as the final outcome and how this motives title holders to certain actions; how intermediary steps influence the behaviour of developers is often missing. The usual understanding is that land holders on public land will run for title registration as soon as they acquire land in order to ensure maximum tenure security. Since title is a key output from the land registration process, many studies rarely question the actions of developers from the point of offer of the plot to production of certificates of title. This study arg ues that it is between these stagesthat important insight on developers' behaviour is gleaned; as often said "the devil is in the details".

\section{Methodological Approach}

\subsection{Theoretical Viewpoint}

The debate in institutional economics on legal title and possession helps to conceptualize the difference between those with and those without certificates of title in the Zambian context. The genesis of this debate was Hodgson's (2015a) assertion that property rights economics devalued legal rights. However others such as Allen (2015) and Barzel (2015) disagree with this assertion, thus igniting debate on 'possession', 'property rights', 'economic rights' and 'legal rights' (see Hodgson, 2015a, b; Allen, 2015; Barzel, 2015; Cole, 2015). In this debate Benito Arrunada seems to support Hodgson's (2015a) position because he also asserted that economic analysis of property rights has disregarded the key advantages of legal property rights (Arrunada, 2012). Arrunada (2014) though linked "possession as evidence for titling", hinting that there was another angle to this debate; that is, there was a 'continuum' from possession to titling. For the purpose of making clear demarcations in this continuum to enable data collection and analysis, this study adopted the distinction between 'property' and 'possession' by conceptualizing the certificate of title (herein referred to as legal title and a final outcome of the titling procession) as 'property' while rights from initial grant through council letters and Ministry of Lands' offer letters as "possession". 
The assertion of the property rights theory is that allotees or land owners with more rights on land will be more motivated to develop than those with less (De Soto, 2000; Navarro and Turnbull, 2013). Thus since full rights of ownership were granted through a certificate of title, it was logical that allotees would rather title the land first before commencement of development. However when the opposite is the norm, as is the case in most Zambian towns, an additional explanation was needed; hence the justification for this paper.

\subsection{Municipality of Kalulushi and Data Collection}

The study area for this research was Kalulushi Town, one of the towns on the Copperbelt Province of Zambia. The town had a population of 75,806 residents in 2010 (Central Statistical Office, 2012). Like a number of local authorities on the Copperbelt Province, Kalulushi Municipal Council has an agency from the Ministry of Lands to process applications for allocation of land in urban areas. Between 2007 and 2010, the town had allocated over 1600 plots, mainly in the expansion areas of Kalengwa North and East. A preliminary survey of the two areas shows houses at various stages of development, thus providing ideal loci for this study.

In the selection of respondents, the study used purposive sampling by focusing on plots where development had already commenced. Data was collected over a period of three months (January - March, 2016). Through this process a total of 180 were identified, although only 140 were interviewed. Analysis of data first used the Fisher's Exact Test to examine which of the two choices, 'possession' or 'property' allotees choose at commencement of physical development. A chi-square test was employed to examine a numbers of variables for possible explanation why allotees choose possession instead of property at the commencement of physical development.

\section{Determinants of Physical Development in Urban Areas in Zambia: Findings}

Initial allocation of public urban land in Zambia was granted through two main documents, an initial recommendation of offer from the local authority and the final offer from the Commissioner of Lands. After submission of cadastral survey diagrams, the Registrar of Lands and Deeds then issues a certificate of title. This system depends on detailed state rules and regulations administered through state and local authority organizatons and agents. This creates an intricate web of relationships (from initial application to title registration) between the State, local authority and allotees interwoven by rules, conditions, responsibilities and duties.

One of the shortcomings of this institutional and organizational structure was the problem of incomplete design resulting in conflicting or unclear policy provisions. Thus the key objective of this study was to investigate decision making behaviour by allotees in situations of seemingly conflicting or unclear policy and legal provisions as is the case in Zambia. As argued in new institutional economics, humans cannot design rules and regulations for every event and action because many of such events and actions cannot be foreseen from inception; hence the existence of incomplete institutions such as extra-legal property rights (Barzel, 1989; North, 1990).

As mentioned earlier, a total of 140 questionnaires out of 180 were successfully administered in Kalengwa North and East, giving an overall success rate of 78 per cent. This was broken down in 52 per cent for Kalengwa North and 48 per cent for Kalengwa East, comprising 97per cent land owners (allottees) and 3 per cent tenants. The entry point for this analysis was to examine the relationship between titled land (property) and untitled (possession) vis a viz commencement of physical development. Results in Table 1showed that the majority (93\%) of land owners commenced physical development without legal title; in other words they commenced development on possession only.

Table 1. Legal title and commencement of physical development

\begin{tabular}{|c|c|c|c|c|}
\hline & & \multicolumn{2}{|c|}{ COMMENCED DEVELOPMENT? } & \multirow[t]{2}{*}{ Total } \\
\hline & & NO & YES & \\
\hline \multirow{3}{*}{$\begin{array}{l}\text { IS THE LAND TITLED? } \\
\text { Total }\end{array}$} & NO & $13(86.7 \%)$ & $112(92.6 \%)$ & $125(91.9 \%)$ \\
\hline & YES & $2(13.3 \%)$ & $9(7.4 \%)$ & $11(8.1 \%)$ \\
\hline & & $15(100.0 \%)$ & $121(100.0 \%)$ & $136(100.0 \%)$ \\
\hline
\end{tabular}

Despite this revelation, a further analysis using Fisher's Exact Test yielded no significant relationship, as revealed by a $p$ value of 0.348 . Thus the follow-up question was to investigate why the majority of land owners opted to commence physical development without legal titles. This was explored by examining relationships between commencement of physical development and a number of possible explanatory variables, starting with social characteristics such as gender, age, education and occupation. Results in Table 2 showed that the majority of allotees were male ( 69.9 per cent) however the chi square test with a $p$ value of 0.755 at 95 per cent confidence level revealed that gender is not a key factor in whether development commenced with possession or with legal title. 
Table 2. Possession, gender and commencement of development

\begin{tabular}{|c|c|c|c|c|}
\hline & & \multicolumn{2}{|c|}{ COMMENCED DEVELOPMENT? } & \multirow[t]{2}{*}{ Total } \\
\hline & & $\mathrm{NO}$ & YES & \\
\hline \multirow{2}{*}{ GENDER } & MALE & $11(73.3 \%)$ & $84(69.4 \%)$ & $95(69.9 \%)$ \\
\hline & FEMALE & $4(26.7 \%)$ & $37(30.6 \%)$ & $41(30.1 \%)$ \\
\hline Total & & $15(100.0 \%)$ & $121(100.0 \%)$ & $136(100.0 \%)$ \\
\hline
\end{tabular}

Age was also an important consideration in this study. Results revealed have that 25 per cent of alloteeswere 33 years and below, 50 per cent were 38 per cent and below while 75 per cent were 46 years and below (see Figure 1). The mean age was 39.8 years with the mode begin 37 years. A further analysis using the chi square test revealed that there was no relationship between commencement of physical development and the age of respondents, represented by a $p$ value of 0.401 at 95 per cent confidence level.

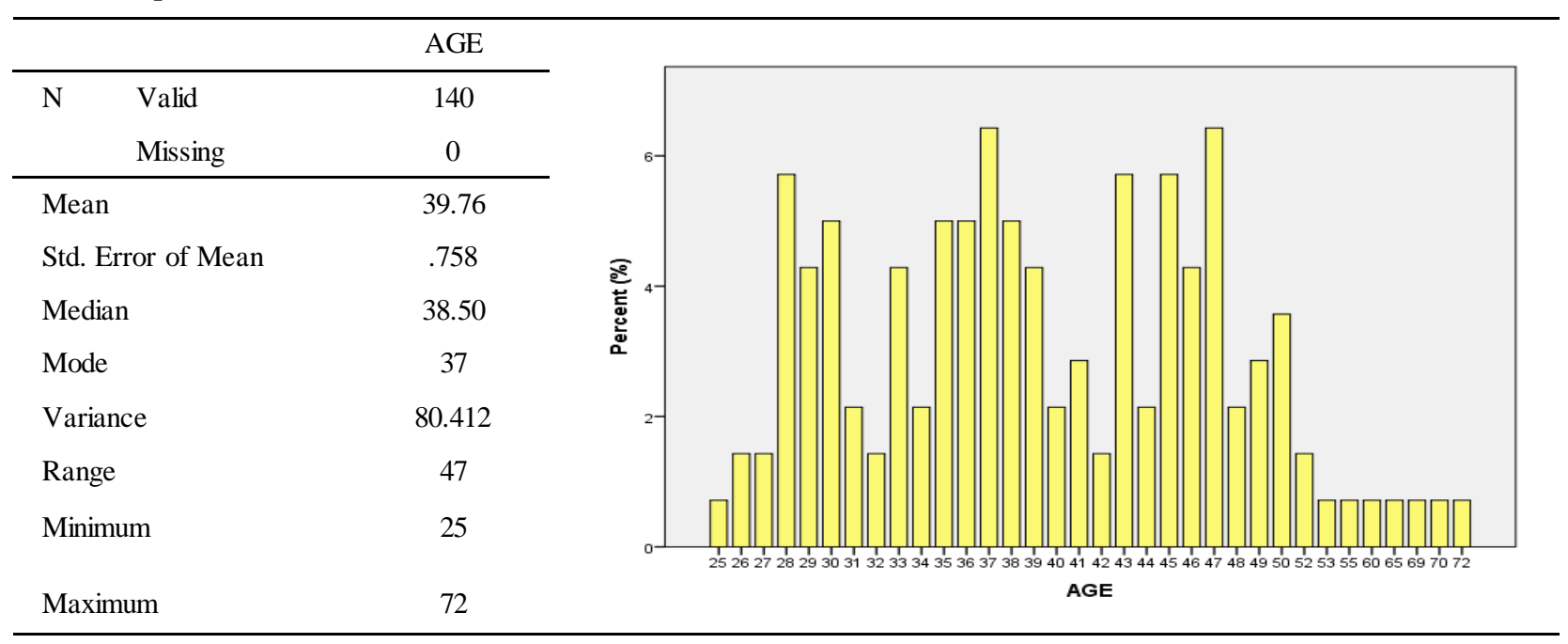

Chi square test: value: $33.362 ; d f=32$; Asymp. Sig. $(2$-sided) $=0.401]$

Figure 1. Possession, age of allotees and commencement of development

Analysis of the education level of land owners coupled with their professions was also used. The reasoning was that since one of the key considerations in the allocation of land is that the applicant should be capable of developing the plot, the level of education will have an impact on the profession and income which then become cardinal in proving capability. This condition often requires the attachment of a payslip or bank statement as proof of the applicant's ability to develop. Overall results in Table 3 showed that 21 per cent have gone up to secondary school level, 48 per cent up to college and 30 per cent up to University level. However, this difference in education cannot be used to explain why most allotees commenced physical development on possession since the chi square test revealed a $p$ value of 0.560 .

Table 3. Possession, level of education and commencement of development

\begin{tabular}{llcrr}
\hline & & \multicolumn{2}{c}{ COMMENCED DEVELOPMENT? } & Total \\
\cline { 2 - 4 } EDUCATION & PRIMARY & NO & $1(0.8 \%)$ & $1(0.7 \%)$ \\
& SECONDARY & $0(0.0 \%)$ & $24(19.8 \%)$ & $29(21.3 \%)$ \\
Total & COLLEGE & $5(33.3 \%)$ & $60(49.6 \%)$ & $65(47.8 \%)$ \\
\hline
\end{tabular}

Chi square test: value $=2.059 ; d f=3$; Asymp. Sig. $(2$-sided) $=0.560$

Overall results on occupation revealed that 23.5 per cent were self-employed, 44.9 per cent were in the private sectors while 31.6 per cent were public officers (Table 4). A further scrutiny of the distribution of professions revealed that about 20 per cent of these allotees work in social services (such as nurses, clinical officers, etc.) while another 17 per cent were in education (teachers, lecturers, etc.). Entrepreneurs and those in corporate services came in third and fourth positions, respectively. These results showed that allotees were spread evenly between self employment, private and public. Overall, it was clear that the majority of allotees were in gainful economic activities which would enable them not only to pay for the plot but also develop. However the chi square results showed a $p$ value of 0.635 at 95 per cent confidence level, revealing that the difference in occupation cannot be used to explain why most allotees commenced developed with possession only. 
Table 4. Possession, occupation and commencement of development

\begin{tabular}{|c|c|c|c|c|}
\hline & & \multicolumn{2}{|c|}{ COMMENCED DEVELOPMENT? } & \multirow[t]{2}{*}{ Total } \\
\hline & & $\mathrm{NO}$ & YES & \\
\hline \multirow{3}{*}{ OCCUPATION } & SELF & $5(33.3 \%)$ & $27(22.3 \%)$ & $32(23.5 \%)$ \\
\hline & PRIVATE & $6(40.0 \%)$ & $55(45.5 \%)$ & $61(44.9 \%)$ \\
\hline & PUBLIC & $4(26.7 \%)$ & $39(32.2 \%)$ & $43(31.6 \%)$ \\
\hline Total & & $15(100.0 \%)$ & $121(100.0 \%)$ & $136(100.0 \%)$ \\
\hline
\end{tabular}

Chi square test: value $=0.908 ; d f=2 ;$ Asymp. Sig. $(2$-sided $)=0.635$

Data analysis was then extended to other possible explanatory variables including acquisition methods, risk perception and awareness on legislative provisions, etc. Results in Table 5 showed that the major modes of acquiring land for development were through the public allocation system (69.9\%) and through the private market (30.1\%). The chi square results however showed that the way land is acquired initially has a very insignificant relationship with the commencement of physical development as revealed by a $p$ value of 0.132 . However the fact that all land in Zambia is public and vested in the President who allocates it through the Commissioner of Lands means that land was being re-sold on the private land market immediately offer letters were received.

Table 5. Possession, mode of acquisition and commencement of development

\begin{tabular}{llccc}
\hline & & \multicolumn{2}{c}{ COMMENCED DEVELOPMENT? } & Total \\
\cline { 2 - 3 } & & NO & YES & \\
\hline \multirow{2}{*}{ ACQUISITION METHOD } & PUBLIC & $13(86.7 \%)$ & $82(67.8 \%)$ & $95(69.9 \%)$ \\
Total & PRIVATE MARKET & $2(13.3 \%)$ & $39(32.2 \%)$ & $41(30.1 \%)$ \\
& & $15(100.0 \%)$ & $121(100.0 \%)$ & $136(100.0 \%)$
\end{tabular}

Chi square test: value $=2.263 ; d f=1$; Asymp. Sig. $(2$-sided $)=0.132$

The way allotees perceived risk was also a major consideration for this study. Results of the analysis between commencement of physical development and risk perception (Table 6) showed a positive relationship, with the chi square test showing a $p$ value of 0.005 at 95 per cent confidence level. These results further showed that 64.5 per cent of those who have commenced developed view risk as being high. To contextualize these results, it is important to reiterate that in Zambia on initial grant of land through the Municipal Council and Ministry of Lands, the allotee faced with a development condition that the land has to be developed within 18 months. Thus although the Lands and Deeds Registry Act stipulates that a certificate of title is the only document that conveys legal ownership, the perception of allotees is that leaving land undeveloped is riskier than not titling it within the de velopment period; making legal title less important at the commencement of physical development. Thus risk of repossession is always present as indicated by 68.4 per cent of allotees, however from the allotees' perspective the risk is higher if the plot remains unde veloped than if developed but not titled.

Table 6. Possession, risk perception and commencement of development

\begin{tabular}{|c|c|c|c|c|}
\hline & & \multicolumn{2}{|c|}{ COMMENCED DEVELOPMENT? } & \multirow[t]{2}{*}{ Total } \\
\hline & & $\mathrm{NO}$ & YES & \\
\hline \multirow{3}{*}{ RISK PERCEPTION } & LOW & $0(0.0 \%)$ & $43(35.5 \%)$ & $43(31.6 \%)$ \\
\hline & HIGH & $15(100.0 \%)$ & $78(64.5 \%)$ & $93(68.4 \%)$ \\
\hline & & $15(100.0 \%)$ & $121(100.0 \%)$ & $136(100.0 \%)$ \\
\hline
\end{tabular}

Chi square test: value $=7.795 ; d f=1$; Asymp. Sig. $(2$-sided) $=0.005$

It was also important to investigate if there was a relationship between commencement of physical development and awareness by allotees of the legislative provision on titling. Results in Tables 7 showed that although 69.4 per cent of allotees were not aware of the legislative provisions, they have nonetheless commenced development. Chi square results showed a $p$ value of 0.006 at 95 per cent confidence level, revealing the fact that this relationship is statistically significant. Overall 65.4 per cent of respondents claimed not to be aware of legislative provisions. However officials at Kalulushi Municipal Council contended that they provide sufficient details on allocation including the full conditions on which land was allocated and the fact that applicants should not commence on the basis of recommendation letters. A perusal of the local authority recommendation letter showed that these conditions were clearly spelt out and with the level of education of most respondents, it is logical to conclude that the majority ought to have known the conditions on development.

Table 7. Awareness of legislative provisions on titling and commencement of development

\begin{tabular}{|c|c|c|c|c|}
\hline & & \multicolumn{2}{|c|}{ COMMENCED DEVELOPMENT? } & \multirow[t]{2}{*}{ Total } \\
\hline & & $\mathrm{NO}$ & YES & \\
\hline AWARE OF LEGISLATIVE & NO & $5(33.3 \%)$ & $84(69.4 \%)$ & $89(65.4 \%)$ \\
\hline PROVISIONS? & YES & $10(66.7 \%)$ & $37(30.6 \%)$ & $47(34.6 \%)$ \\
\hline Total & & $15(100.0 \%)$ & $121(100.0 \%)$ & $136(100.0 \%)$ \\
\hline
\end{tabular}

The analysis was then extended to costs involved in acquisition and development of land, specifically, fees on application 
for land, amount spent on the plots so far (i.e. development fees, titling, connection of utilities) and amount spent on the construction of the building itself. Results in Figure 2 showed that most of the allotees paid K300.00 as application fees for their plots. However a further scrutiny showed no relationship between commencement of development and this cost, as revealed by a $p$ value of 0.509 at 95 per cent confidence level.

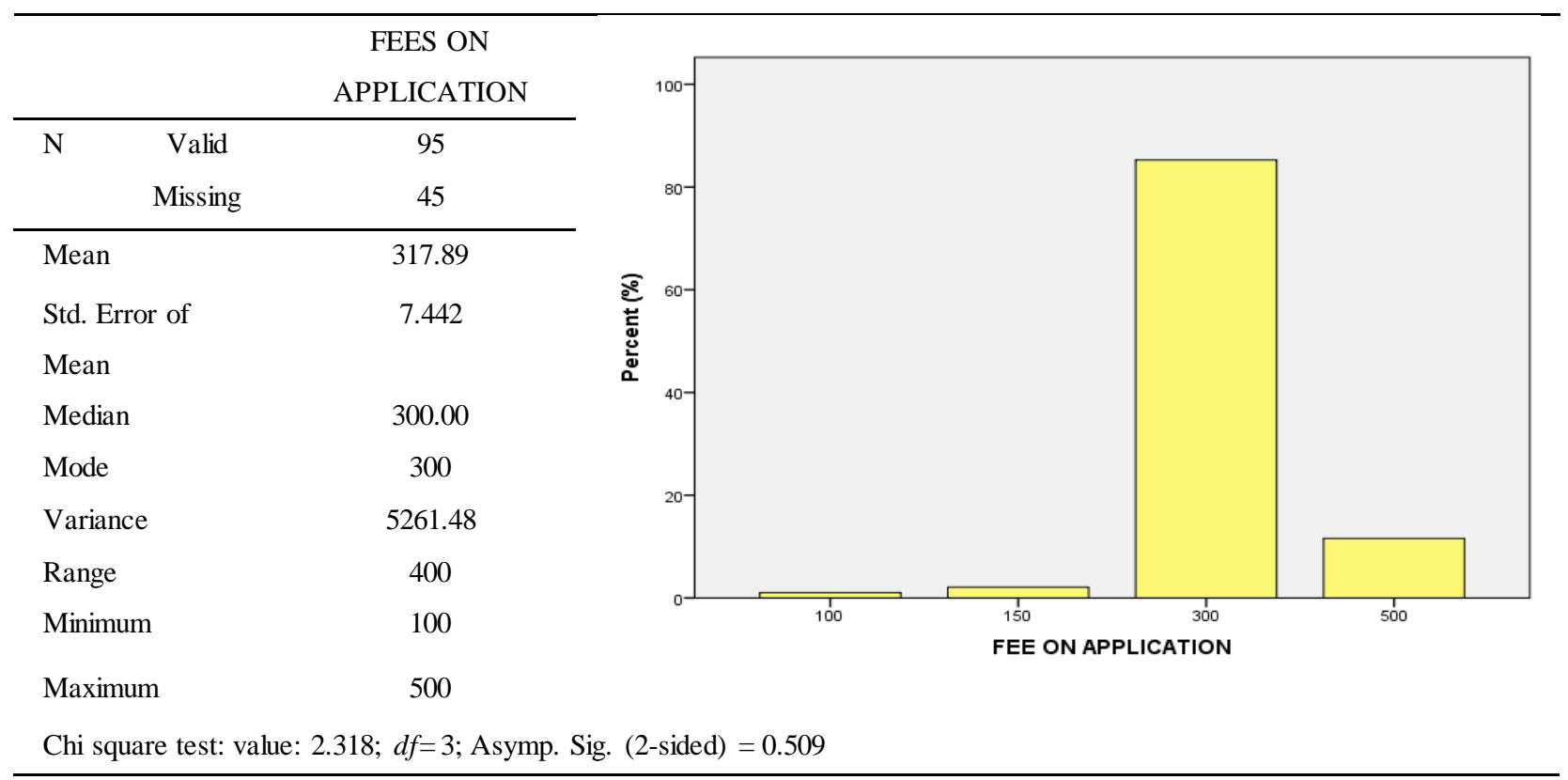

Figure 2. Possession, fee on application for land and commencement of development

The actual amount spent so far on the plots varied widely between K150.00 and K48,000.00; with a mean of K9,505.39. Figure 3 showed a median of $\mathrm{K} 1,800$, revealing that although the majority have commenced development, the amounts spent on the plot itself was still very little. However the chi square results showed a strong relationship ( $p$ value of 0.000 at 95 per cent confidence level) between commencement of development and amount spent on the plot so far. The implication was that the more allotees spend on the plot, the more likely they were to commence development.

This was clearly seen when amounts spent on the construction of the building were scrutinised. Results in Figure 4 showed vividly that the focus of the allotee was to complete the house on the plot, with results showing a range of K60,000 to K450,000. In fact a mean of K231, 911.11 showed ability by most allotees not only to develop the land but also obtain title in the process. But as noted in this study, many were not in a hurry to obtain title. 


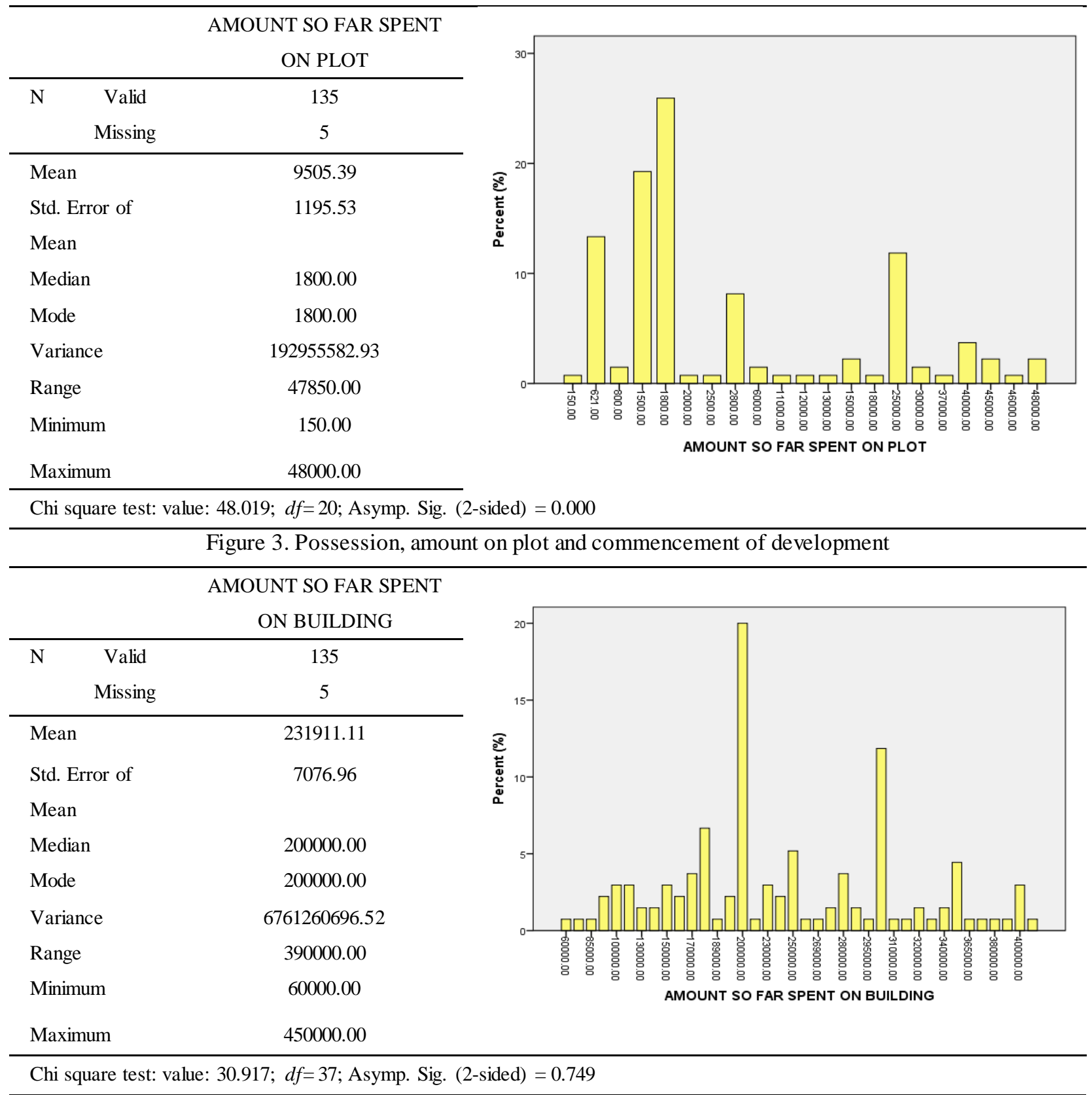

Figure 4. Possession, amount on building and commencement of development

Results showed that besides costs directly related to the acquisition of plots, commencement of physical development has no significant relationship with fees on application or cost of construction. Thus results revealed that the higher the cost involved in acquiring the plot, the more eager the land owner is in ensuring that construction on the land commences. This can be linked to results on perception on risks in that the more one invests in the purchasing of a plot, the higher will be the loss if that land is repossessed; in other words the land owner risks more, hence the need to commence development quickly.

\section{Conclusion and Policy Implications}

The entry point for this study was that there were some inconsistencies between the terms and conditions on land allocation derived from the Lands Act and the law on titlingas stipulated in the Lands and Deeds Registry Act. This has left most beneficiaries from the land allocation system in a position where they have to carefully strategise to navigate this situation. Thus although allottees were reasonably aware of the need to obtain title, their focus was mostly on physical possession which is done even as early as on the recommendation letter. Once an allotee was on the plot, there is no urgency in titling the land especially because they were also under pressure to develop these plots within 18 months to avoid repossession by the State. In such an environment of limited financial resources, the first option was to put a physical structure on the ground and use possession as insurance against repossession. Observations on the ground 
showed that this is especially so during periods of high political tension, particularly during election times as was experienced during the campaigns for the 2016 Presidential and Parliamentary elections. During such periods the State was often seen to be reluctant to enforce legal provisions such as the development control code.

These results have a number of policy implications. Firstly, there was a need to reconcile the provisions of the Lands and Deeds Registry Act and de velopment conditions derived from the Lands Act and incorporated in recommendation and offer letters. The State cannot on one end ask allotees to process titles through its system which takes over 18 months and still require the developer to have de veloped by that point with a caveat that they do so at their own risk. The seemingly conflicting provisions of the law and terms of allocation create indecisiveness amongst allotees. In an environment of limited finances, allotees have to make a choice; either to proceed straight to titling and delay the commencement of development or start development and delay titling. This study showed that they choose the latter.

Secondly, with the issuance of Statutory Instrument (SI) No. 73 of 2015 on land pricing, it was clear that government's intention is to sell land at market prices. In assessing selling prices for land, government uses comparative data from the private land market (GRZ, 2015). Government's argument was that if allotees were able to resell these plots at much higher prices on the secondary market immediately after being allocated, then the State should be the one to benefit from these higher prices, hence the argument of the land value capture concept (Ingram and Hong, 2012; Walters, 2012; Kitchen, 2013; Mathur and Smith, 2013; Frismanet al, 2015). However the counter argument was that plots sold by private developers, such as in the Meanwood estates in the city of Lusaka were often serviced and surveyed. Thus the duty on government was that it should equally provide services up to the same standard as privately sold plots in various estates; meaning that land should be sold fully serviced with title ready to be assigned to the allotee. The status quo of allocating un-surveyed and un-serviced land shifts the burden from the State to the allotee and in the process delaying both the titling and development of the plot.

Thirdly, the study revealed that the majority of respondents were not aware of the law pertaining to land registration and development. This is an indication that the local authority may not adequately be educating allotees on initial allocation what the procedures going forward were. Hence for the majority of respondents, a recommendation letter from the local authority is a sufficient document on which to commence physical development.

A number of recommendations emit from this study to aid reformation of policy on land allocation and urban development. For instance at least 29 per cent of allotees felt that all the paper work on land should be done at once while the other 20 per cent thought that most of this should be done at the district level through a decentralised system. However other 21 per cent felt that monitoring development on land was more important to ensuring that allotees also registered their land. Other suggestions given included the introduction of online title processing, issuing building permits after title and changing certain provisions in policy and law.

Thus the question for this study was not whether title is or is not important for land ownership but why an allotee could choose to commence development at mere possession with its perceived repossession risks given that the option for registration of title is open. This posits that title is often required beyond physical development, for instance in cases of transfer in the property market or when using property for collateral purposes. This study pointed to the need to undertake a thorough review of processes and procedures to identify loopholes in the system and also make them more user-friendly. Seeing that titling is a more expensive form of registration, and cited as a hindrance to titling by a number of respondents, government should consider simplifying the process with the intension of making it cheaper.

It also appears that tenure security is perceived differently on land acquired through a government system or that acquired through the private market. For land acquired through the public system the fact that the offer letter is from the State or its appointed agency gives allottees sufficient tenure security. It can thus be concluded that the major action for securing a government grant on urban land is not titling but physical development; once the plot is developed, the threat of repossession by the State is almost extinguished.

\section{References}

Alhassan, O., \& Manuh, T. (2005).Research Report 5: Land registration in Eastern and Western Regions, Ghana. Nottingham, UK: IIED.

Allen, D. W. (2015). On Hodgson on property rights. Journal of Institutional Economics, 11(4), 711-717. https://doi.org/10.1017/S1744137415000132

Amanor, K. S. (2012). 'Land Governance in Africa: How historical context has shaped key contemporary issues relating to policy on land'. Framing the Debate Series No. 1, ILC, Rome.

Arko-Adjei, A. (2011). Adapting land administration to the institutional framework of customary tenure The case of peri-urban Ghana. MSc Thesis. Delft University of Technology.(Unpublished).

Arrunada, B. (2012). Property as an economic concept: Reconciling legal and economic conceptions of the property rights 
in a Coasean framework. Barcelona GSE Working Paper Series, Working Paper No. 614. https://doi.org/10.1007/s12232-012-0150-4

Arrunada, B. (2014). The titling role of possession. Paper presented at the ISNIE 18th Annual Conference, Duke University, June 19-21, Durham, North Carolina.

Barzel, Y. (1989). Economic Analysis of Property Rights. Cambridge: Cambridge University.

Barzel, Y. (2015). What are 'property rights', and why do they matter? A comment on Hodgson's article. Journal of Institutional Economics, 11(4), 719-723. https://doi.org/10.1017/S1744137415000181

Besley, T. J. (1995). Property rights and investment incentives: Theory and evidence from Ghana. Journal of Political Economy, 103(5), 903-937. https://doi.org/10.1086/262008

Besley, T. J., \& Ghatak, M. (2009). Property rights and economic development. CEPR Discussion Paper No DP7243. Retrieved 6 August 2016, from http://ssrn.com/abstract=1372563

Central Statistical Office (CSO). (2012).Census of Population and Housing 2010 National Analytical Report. Lusaka: CSO.

Chavez, R. (n.d). Incremental Housing: The Past and Future Dwelling Solution for the Poor. Retrieved 20 December 2016, from http://web.mit.edu/incrementalhousing/articlesPhotographs/pdfs/CHAVEZ-Formal_Incremental_Housing.pdf

Cole, D. H. (2015). 'Economic Property Rights' as 'Nonsense upon Stilts': A Comment on Hodgson. Journal of Institutional Economics, 11(4), 1-6. https://doi.org/10.1017/S174413741500020X

Crabtree-Condor, I., \& Casey, L. (2012).Lay of the land Improving land governance to stop land grabs. Retrieved 20 December 2016, from

http://www.actionaid.org/sites/files/actionaid/lay_of_the_land_-_improving_land_governance_to_stop_land_grabs _low_res_1.pdf

Dale, P. F., \& McLaughlin, J. D. (1988).Land information management: An introduction with special reference to cadastral problems in Third World countries. Oxford: Oxford Press.

De Soto, H. (2000). The mystery of capital: Why capitalism triumphs in the west and fails everywhere else. New York: NY. Basic Books.

Deininger, K., Selod, H., \& Burns, A. (2012). The Land Governance Assessment Framework: Identifying and Monitoring Good Practice in the Land Sector. Washington, D.C.: World Bank.

Derby, F. W. (2002). Improving and facilitating land title registration processes in Tanzania. FIG XXII International Congress, 19-26 April, Washington, D.C.

Domeher, D., \& Abdulai, R. (2012).Land registration, credit and agricultural investment in Africa. Agricultural Finance Review, 72(1), 99-100. https://doi.org/10.1108/00021461211222141

Enemark, S. (2003). Capacity building for developing sustainable land administration infrastructures. Paper presented at WPLA/FIG Workshop on Spatial Information Management for Sustainable Real Estate Markets and Best Practice Guidelines on Nation-wide Land Administration, 28-31 May, Athens.

Enemark, S. (2012). Sustainable land governance: Spatially enable, fit for purpose, and supporting the Global agenda. Paper presented at the 'Annual World Bank Conference on Land and Poverty' The World Bank, April 23-26, Washington D.C.

Enemark, S., \& van der Molen, P. (2006). A framework for self-assessment of capacity needs in land administration. In Shaping the change: XXIII International FIG Congress: Proceedings. FIG Denmark.

Enemark, S., McLaren, R., \& van der Molen, P. (2010). Land Governance in Support of The Millennium Development Goals A New Agenda for Land Professionals.FIG Publication No. 45, FIG / World Bank.

Frisman, P., Poole, H., \& Rappa, J. (2015).Land value recapture to finance infrastructure. Retrieved 19 December 2016, from https://www.cga.ct.gov/2015/rpt/pdf/2015-R-0101.pdf

Government of the Republic of Zambia (GRZ). (1914). Land and Deeds Registry Act. Lusaka: Government Printers.

Government of the Republic of Zambia (GRZ). (1996). Lands Act. Lusaka: Government Printers.

Government of the Republic of Zambia (GRZ). (2015). The Lands (Ground Rent, Fees and Charges) (Amendment) Regulations. Lusaka: Government Printers.

Haran, N. P. (2013). Land governance: Need to protect and use judicially public lands. Retrieved 28 November 2016, from www.napsipag.org/pdf/d_ab_14.pdf 
Hickey, R., \& Sturtevant, L. (2015). Public Land \&Affordable Housing in the Washington DC Region: Best practices and recommendations. Retrieved 17 December 2016, from http://washington.uli.org/wp-content/uploads/sites/56/2015/02/ULI_PublicLandReport_Final020215.pdf

Hodgson, G. M. (2015a). Much of the 'economics of property rights' devalues property and legal rights. Journal of Institutional Economics, 11(4), 683-709. https://doi.org/10.1017/S1744137414000630

Hodgson, G. M. (2015b). What Humpty Dumpty might have said about property rights and the need to put them back together again: a response to critics. Journal of Institutional Economics, 11(4), 731-747.https://doi.org/10.1017/S1744137415000260

Ingram, G. K., \& Hong, Y. (2012). Land Value Capture: Types and Outcomes. In: G.K. Ingram, \& Y. Hong (eds.), Value Capture and Land Policies (pp. 3-18). Cambridge: Lincoln Institute of Land Policy.

Kanji, N., Cotula, L., Hilhorst, T., Toulmin, C., \& Witten, W. (2005). Can land registration Serve poor and marginalisedgroups? Nottingham UK: Russell Press.

Kitchen, H. (2013). Property tax: Asituational analysis and an overview. In: W.K. McCluskey, G. C, Cornia, L. C. Walters (Eds.), APrimer on Property Tax: Administration and Policy (pp. 1 -40). Blackwell Publishing Ltd. United Kingdom: Oxford University,

Maoulidi, S. (2004).Critical analysis of the land laws, Land Rights Research and Resource Institute (HAKIARDH). Retrieved 7 August 2016, from http://www.hakiardhi.org/index.php?option=com_docman\&task=doc_download\&gid=72\&Itemid=80

Mathur, S., \& Smith, A. (2013). Land value capture to fund public transportation infrastructure: Examination of joint development projects' revenue yield and stability. Transport Policy, 30, November, 327-335.https://doi.org/10.1016/j.tranpol.2013.09.016

Navarro, I. A., \& Turnbull, G. K. (2013). Property Rights and Urban Development: Initial Title Quality Matters Even When it No Longer Matters. Journal of Real Estate Finance and Economics.

North, D. C. (1990).Institutions, institutional change and economic performance. New York: Cambridge Uni versity Press. https://doi.org/10.1017/CBO9780511808678

Österberg, T. (2006). Land Administration for Economic Development - Experiences from Institutional Development Projects. XXIII FIG congress, Shaping the Change, October, 8 - 13 October, Munich, German.

Palmer, D., Fricska, S., \& Wehrmann, B. (2009).Towards improved land governance. Land Tenure Working Paper 11, FAO/UN Human Settlements Programme.

Sevatdal, H. (2002). Land Administration and Land Management - An Institutional Approach. FIG XXII International Congress, April 19-26, Washington, D.C.

Steudler, D. (2004). A framework for the evaluation of land administration systems. Unpublished PhD thesis.The University of Melbourne.

Tipple, G. (1991).Self Help Transformations of Low Cost Housing.An introductory Study. CARDO in association with the International Urban Press, Newcastle upon Tyne.

UNECE. (2005). Social and Economic Benefits of Good Land Administration.Second edition. New York and Geneva. Retrieved 20 December 2016, from http://www.unece.org/index.php?id=10964.

Walters, L. C. (2012). Land value capture in policy and practice. Retrieved 18 December 2016, from www.landandpo verty.com/agenda/pdfs/paper/walters_full_paper.pdf

Williamson, I., Enemark, S., \& Wallace, J. (eds) (2006). Sustainability and land administration systems: Proceedings of the expert group meeting on incorporating sustainable development objectives into ICT enabled land administration systems. Department of Geomatics, University of Melbourne, Melbourne.

Zimmermann, W. (2007). Good governance in public land management. Land Reform 2007/2. Retrieved 16 December 2016, from http://www.fao.org/3/a-a1423t/a1423t01.pdf

\section{Copyrights}

Copyright for this article is retained by the author(s), with first publication rights granted to the journal.

This is an open-access article distributed under the terms and conditions of the Creative Commons Attribution license which permits unrestricted use, distribution, and reproduction in any medium, provided the original work is properly cited. 